\title{
The Relationship Between the Reputation of the Sports Team Perceived by University Students and Their Psychological Commitments to Their Teams
}

\author{
Ramazan Sanlav \\ Vocational School of Social Sciences, \\ Department of Sports Management, Istanbul Medipol University, Turkey \\ Kavacık Main Campus, 34810, Beykoz, Istanbul, Turkey \\ Tel: 90-507-524-66-34 E-mail: rsanlav@medipol.edu.tr \\ Pero Duygu Dumangöz (Corresponding author) \\ Department of Physical Education, Istanbul Technical University \\ Ayazaga Campus, 34469, Maslak, Istanbul, Turkey \\ Tel: 90-541-929-9267Ｅ-mail: perophd@gmail.com
}

Received: April 17, 2021 Accepted: May 16, $2021 \quad$ Published: May 31, 2021

doi:10.5296/jei.v7i1.18539 URL: https://doi.org/10.5296/jei.v7i1.18539

\begin{abstract}
This study aims to examine the relationship between the reputation of sports team perceived by university students and their psychological commitment to their teams and to determine whether these two variables differ according to variables such as gender, age, department of university, the status of membership to a fan union, and the team the students supported. This is a quantitative study utilizing descriptive scanning model. The population of the study consists of students studying in universities on the European Side of Istanbul, and the sample consists of 219 students contacted by the random selection method. The study applied personal information form prepared by the researcher, the Spectator-Based Sports Team Reputation Scale (SSTR), which was developed by Wonseok et al. (2015) and the Fan Psychological Commitment Scale (FPCS), which was developed by Matsuoka (2001) in order to collect data in the study. SPSS 20.0 software package was used for data analysis. The collected data were examined with Kolmogorov-Smirnov and distribution graphs in terms of normal distribution in addition to descriptive statistics. Mann-Whitney $U$ and Kruskal-Wallis
\end{abstract}


tests were used to compare the data based on the number of variables. Post-hoc analyses were conducted by Mann-Whitney U test using Bonferroni correction and relationships between variables by Spearman's correlation analysis. The prediction of the FPCS score by SSTR score was evaluated through linear regression analysis. The error margin was accepted as $\mathrm{p}<$ 0.05. A positive significant relationship was found between FPCS and SSTR variables perceived by university students according to the research results $(p<0.05)$. The results have strategic implications for managers who can evaluate the team reputation and the psychological commitment of the fan to the team in this context and encourage this for more fan participation.

Keywords: Spectator, Psychological commitment, Spectator-based reputation, Sport marketing

\section{Introduction}

Football has become a popular sports branch day by day with its thousands of years of history. It is undoubtedly the fans who give football this momentum. Therefore, football fans constitute the most critical target audience of marketers since football has a large share in the sports industry. Knowing what the fans feel, what they perceive, how they behave, and the level of their commitment, knowing all their aspects, in short, play a pivotal role in the success of sports organizations.

Fans make significant contributions to the financial strength of their teams. Therefore, a success achieved in national or international platforms belongs to a whole which includes not only the teams but also the fans (Yavuz Eroğlu \& Eroğlu, 2020).

So who is a fan? A fan is a person who has a sense of commitment to the team they support, support all kinds of club activities, and benefit from the services of the club they are a fan of for a certain fee (Göksel et al., 2020). There is also an increase in the sense of belonging to the team as the fan's level of commitment to the team increases (Wann, 1997, cited in Göksel et al., 2020).

Sports marketers must manage their teams, leagues, and organizations to create brand value both indoors and outdoors with a large amount of money circulating in the sports industry (Ross, 2006). In addition, team managers must not only manage their teams but also identify the factors that will contribute to the team's economic success and help them develop a competitive advantage. One of these factors is the reputation of the sports team (Ross, 2006; Jang et al., 2015; Yousaf et al., 2020).

The researchers could not reach a consensus on the conceptualization of the sports team reputation, which received limited attention in the context of sports despite its critical importance (Jang et al., 2015; Yousaf et al., 2020). According to Jang et al. (2015), reputation is a perception based on the fans' response to their experience from previous interactions with the activities of the sports team.

Reputation is an intangible asset according to Gotsi and Wilson (2001). So much so that it is judged by the direct experience of its stakeholders and is based on the actions of institutions 
over time. It makes significant contributions to financial performance. A positive reputation can affect customer-centered outcomes such as trust, respect, loyalty, and commitment (Ponzi et al., 2011; Hong \& Yang, 2009; Caruana \& Ewing, 2010). Nguyen and Leblanc (2001) concluded based on their studies that corporate image and reputation had positive effects on the future tendencies of customers.

Jang et al. (2015), who thought that measuring the reputation of the sports team and its impact on fan-based variables required multidimensional scales, conducted his research in this direction and developed a multidimensional scale using both quantitative and qualitative criteria. The six subscales of the scale called Spectator-Based Sports Team Reputation (SSTR) were verified as team performance, team tradition, team social responsibility, spectator-orientation, management quality, and financial soundness. The team performance subscale is related to the perception of the quality of the performance that leads the sports team to success. The team tradition subscale reflects fans' perception of overall success and business success so far. The social responsibility of the team is the fans' perception of their commitment to the sports team to contribute to their relationship with the community and social development. Spectator-orientation subscale is the perception of where it is placed and how much attention is paid by the sports team supported by the fan. Management quality subscale refers to the perception of the sports team's superior management quality and strategic vision compared to other similar organizations. The financial soundness subscale refers to the perception of the financial strength of the sports team supported by the fan.

The reputation of the sports team is determined by how the fans feel about the sports teams. The primary purpose of this research is to determine whether there is a relationship between the reputation of the sports team perceived by the university students and their psychological commitment to their teams, and which variables may affect this in which direction, if any.

Tüfekçi and Bağış (2016) explained the concept of psychological commitment as an attitude that plays an important role in the emergence of beneficial attitudes and behaviors and which also includes loyalty behaviors. One of the factors affecting participation in sports organizations is the commitment to the team (Hill \& Green, 2000).

Two dimensions of the concept of psychological commitment to the team can be mentioned. The first of these is the attitudinal dimension. Levels of fans' psychological commitment will increase over time if they feel a sense of belonging to their teams (Gladden \& Funk, 2001; Wang et al., 2011). The second dimension is the behavioral dimension. This scale includes repetitive behaviors such as buying tickets, buying team colors, or products with a team logo (Mahony et al., 2000; Shawn \& Philip, 2012).

There have been many studies examining the relationship between reputation and commitment until now (Anderson et al., 1994; Hart \& Rosenberger, 2004; Suchao-in et al., 2021), but little is known about the relationship between the reputation of the sports team and the psychological commitment of the fan. It is expected that this study will contribute to the field by revealing the relationship between the perceived reputation of the sports team, which are very important especially in marketing communication, and fan commitment. 


\section{Macrothink}

\section{Method}

This study aims to determine the relationship between the reputation of the sports team perceived by university students and their psychological commitment to their teams and to examine these according to some variables. This is a quantitative study utilizing descriptive scanning model in this context.

(1) Is there a relationship between the reputation of the sports team perceived by university students and their psychological commitment to their teams?

(2) Is there a relationship between the reputation of the sports team perceived by university students according to variables such as gender, age, department of university, the status of membership to a fan union, and their psychological commitment to their teams?

The hypotheses formed and tested within the research are as follows:

H1: There is a difference between the reputation of the sports team perceived by the participants according to their gender and their psychological commitment to their teams.

$\mathrm{H} 2$ : There is a difference between the reputation of the sports team perceived by the participants according to their age and their psychological commitment to their teams.

H3: There is a difference between the reputation of the sports team perceived by the participants according to their department of university and their psychological commitment to their teams.

H4: There is a difference between the reputation of the sports team perceived by the participants according to their membership to a fan union and their psychological commitment to their teams.

H5: There is a difference between the reputation of the sports team perceived by the participants according to the team they support and their psychological commitment to their teams.

H6: There is a linear relationship between the reputation of the sports team perceived by the participants and their psychological commitment to their teams.

\subsection{Research Group}

The population of the study consists of students studying in universities on the European Side of Istanbul, and the sample consists of 219 university students contacted by the random selection method.

The scales used within the research were first transferred to the online environment in Google documents and then communicated to university students through virtual networks. 263 fans studying at universities on the European Side of Istanbul filled out the scales voluntarily, but 219 were considered valid because incomplete filled scales were detected. 


\subsection{Measurements}

A personal information form and two scales were used to collect the data. Necessary permissions were obtained from the scientists who adapted the scale to Turkish before the scales were used. The forms and scales used within the research are as follows;

Personal Information Form: It is a form consisting of a total of 6 questions designed by the researcher to determine the variables of gender, age, department of university, the status of membership to a fan union, and the team that the participants support.

The Spectator-Based Sports Team Reputation (SSTR): It is a scale consisting of 19 items and 6 dimensions developed by Wonseok et al. (2015). The adaptation to Turkish and validity and reliability study was conducted by Yavuz Eroğlu and Eroğlu (2020). It is a 7-point Likert-type scale as strongly disagree (1), slightly disagree (2), disagree (3), undecided (4), agree (5), slightly agree (6), and strongly agree (7). The scale has subscales of team performance, team tradition, team social responsibility, spectator orientation, management quality, and financial performance. Cronbach's alpha reliability coefficients of the scale and its subscales for this study are as follows: Team performance was calculated as .90 , team tradition .90 , team social responsibility .87, spectator-orientation .73, management quality .92 , financial performance .78, and the whole scale as .94 .

The Fan Psychological Commitment Scale (FPCS): The validity and reliability study of the scale developed by Matsuoka in 2001 in the Turkish version was conducted by Bozgeyikli et al. (2018). It is a 5-point Likert-type scale consisting of 30 items and 6 dimensions: Strongly disagree (1), disagree (2), undecided (3), agree (4), and strongly agree (5). The scale has subscales of personal identity, emotional commitment, resource cost, psychological cost, social obligation, and regional commitment. Cronbach's alpha reliability coefficients of the scale and its subscales for this study are as follows: Personal identity was calculated as .86, emotional commitment as .90 , resource cost as .79, psychological cost as .83, social obligation as .63, regional commitment as .87 , and the whole scale as .95 .

The high Cronbach's Alpha values of the scales used within this research indicate that they are reliable for data collection.

\subsection{Analysis of Data}

The categorical data were expressed as frequency and percentage, and continuous data were expressed as mean and standard deviation. The data were examined with Kolmogorov-Smirnov and distribution graphs in terms of normal distribution. Mann-Whitney $\mathrm{U}$ and Kruskal-Wallis tests were used to compare the data according to the number of variables. Post-hoc analyses were performed by Mann-Whitney $U$ test using Bonferroni correction. Relationships between variables were performed by Spearman's correlation analysis. The prediction of Fan Psychological Commitment score by Spectator-Based Sports Team Reputation scale score was evaluated through linear regression analysis. The data were analyzed by SPSS 20.0 package software. Statistical significance level was defined as $\mathrm{p}<$ 0.05 . 


\section{Results}

This part presents descriptive statistics on the demographic characteristics of university students and analyses conducted for research purposes.

Table 1. Participants' descriptive statistics on demographic variables

\begin{tabular}{|c|c|c|}
\hline & n & $\%$ \\
\hline \multicolumn{3}{|l|}{ Gender } \\
\hline Female & 84 & 38.4 \\
\hline Male & 135 & 61.6 \\
\hline \multicolumn{3}{|l|}{ Age } \\
\hline $17-20$ & 62 & 28.3 \\
\hline $21-23$ & 124 & 56.6 \\
\hline 24 or more & 33 & 15.1 \\
\hline \multicolumn{3}{|l|}{ Department of University } \\
\hline Sports Sciences & 112 & 51.1 \\
\hline Other than Sports Sciences & 107 & 48.9 \\
\hline \multicolumn{3}{|l|}{ Membership to a Fan Union } \\
\hline Yes & 68 & 31.1 \\
\hline No & 151 & 68.9 \\
\hline \multicolumn{3}{|l|}{ Team Supported } \\
\hline Fenerbahçe & 64 & 29.2 \\
\hline Beşiktaş & 44 & 20.1 \\
\hline Galatasaray & 74 & 33.8 \\
\hline Trabzonspor & 26 & 11.9 \\
\hline Other & 11 & 5.0 \\
\hline TOTAL & 219 & 100 \\
\hline
\end{tabular}

$61.6 \%$ of the participants were male, and $38.4 \%$ were female. $28.3 \%$ were in the $17-20$ age group, $56.6 \%$ in the $21-23$ age group, and $15.1 \%$ in the 24 and above age group. The rate of participants studying in the department of sports sciences is $51.1 \%$ and the rate of participants studying in a department other than sports sciences is $48.9 \% .31 .1 \%$ of the participants have a 


\section{Ml Macrothink}

membership to a fan union and $68.9 \%$ do not have a membership to a fan union. $29.2 \%$ of the participants supported Fenerbahçe, 20.1\% Beşiktaş, 33.8\% Galatasaray, 11.9\% Trabzonspor, and $5.0 \%$ other teams.

Table 2. Mann-Whitney U test results of FPCS and SSTR scores by "gender"

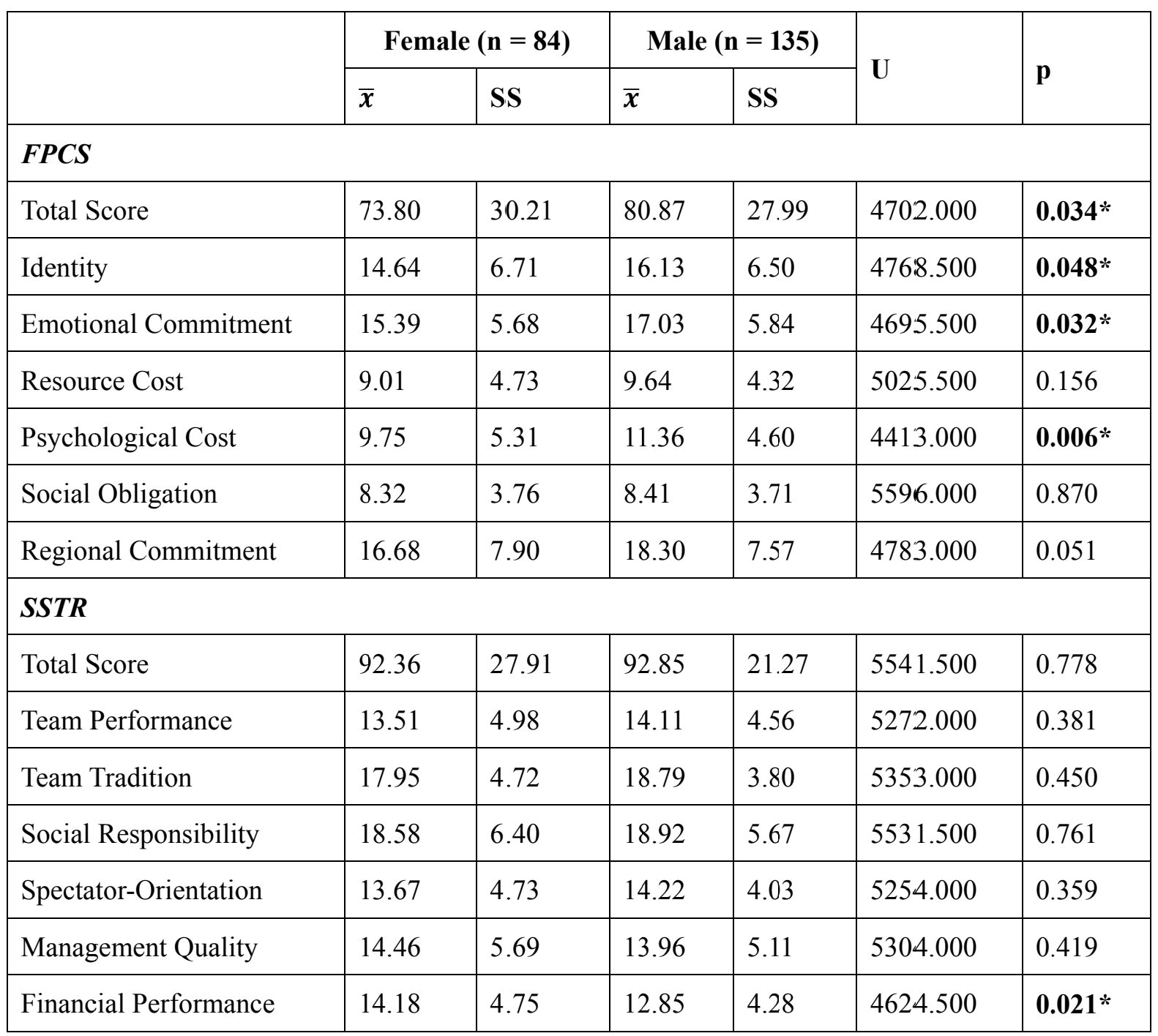

Note. ${ }^{*}: \mathrm{p}<0.05$.

Table 2 shows the results of the difference between the total scale score and the subscale scores by gender. The total score of the Fan Psychological Commitment Scale and the personal identity subscale, emotional commitment subscale, and psychological cost subscale scores of this scale were significantly higher in male participants compared to female participants $(\mathrm{p}<0.05)$.

There was a statistically significant difference in the financial performance subscale of Spectator-Based Sports Team Reputation Scale according to gender. The score of male 
participants in this subscale was significantly lower than the score of female participants $(\mathrm{p}<$ $0.05)$.

Table 3. Kruskal-Wallis test results of FPCS and SSTR scores by "age"

\begin{tabular}{|c|c|c|c|c|c|c|c|c|c|}
\hline & \multicolumn{2}{|c|}{$\begin{array}{c}17-20^{1} \\
(n=62)\end{array}$} & \multicolumn{2}{|c|}{$\begin{array}{c}21-23^{2} \\
(n=124)\end{array}$} & \multicolumn{2}{|c|}{$\begin{array}{c}24 \text { and above } \\
\quad(n=33)\end{array}$} & \multirow[t]{2}{*}{$x^{2}$} & \multirow[t]{2}{*}{$\mathbf{p}$} & \multirow[t]{2}{*}{ post-hoc } \\
\hline & $\overline{\boldsymbol{x}}$ & SS & $\bar{x}$ & SS & $\bar{x}$ & SS & & & \\
\hline \multicolumn{10}{|l|}{ FPCS } \\
\hline Total Score & 73.80 & 30.21 & 80.87 & 27.99 & 78.16 & 29.00 & 0.043 & 0.979 & - \\
\hline Identity & 14.64 & 6.71 & 16.13 & 6.50 & 15.56 & 6.60 & 0.480 & 0.787 & - \\
\hline Emotional Commitment & 15.39 & 5.68 & 17.03 & 5.84 & 16.40 & 5.82 & 0.130 & 0.937 & - \\
\hline Resources Cost & 9.01 & 4.73 & 9.64 & 4.32 & 9.40 & 4.48 & 1.273 & 0.529 & - \\
\hline Psychological Cost & 9.75 & 5.31 & 11.36 & 4.60 & 10.74 & 4.94 & 0.213 & 0.899 & - \\
\hline Social Obligation & 8.32 & 3.76 & 8.41 & 3.71 & 8.38 & 3.72 & 6.648 & $0.036 *$ & $2-3$ \\
\hline Regional Commitment & 16.68 & 7.90 & 18.30 & 7.57 & 17.68 & 7.72 & 1.095 & 0.578 & - \\
\hline \multicolumn{10}{|l|}{ SSTR } \\
\hline Total Score & 96.23 & 17.77 & 89.48 & 27.07 & 97.94 & 20.10 & 3.064 & 0.216 & - \\
\hline Team Performance & 13.82 & 4.60 & 13.33 & 4.79 & 16.06 & 4.20 & 9.182 & $0.010 *$ & $2-3$ \\
\hline Team Tradition & 19.35 & 3.35 & 17.76 & 4.80 & 19.48 & 2.25 & 3.891 & 0.143 & - \\
\hline Social Responsibility & 19.56 & 4.24 & 18.18 & 6.53 & 19.64 & 6.31 & 2.230 & 0.328 & - \\
\hline Spectator-Orientation & 14.82 & 3.32 & 13.46 & 4.75 & 14.55 & 4.01 & 3.528 & 0.171 & - \\
\hline Management Quality & 15.03 & 4.94 & 13.60 & 5.61 & 14.58 & 4.82 & 2.953 & 0.228 & - \\
\hline Financial Performance & 13.63 & 3.95 & 13.15 & 4.71 & 13.64 & 4.78 & 0.792 & 0.673 & - \\
\hline
\end{tabular}

Note. ${ }^{*}: \mathrm{p}<0.05$.

Table 3 shows the results of the analysis of the scale scores by age. A statistically significant difference was found in the social obligation subscale of the Fan Psychological Commitment Scale. The post hoc test on which group the difference originated from, showed that the score of the participants in the 21-23 age group was significantly higher compared to the score of the participants who were 24 years old and above $(\mathrm{p}<0.05)$.

There was a statistically significant difference also in the team performance subscale of Spectator-Based Sports Team Reputation Scale according to age. The post hoc test on which 
group the difference originated showed that the score of the participants aged 24 years old and above was significantly higher compared to the score of the participants aged 21-23 years $(\mathrm{p}<0.05)$.

Table 4. Mann-Whitney U test results of FPCS and SSTR scores by "department of university"

\begin{tabular}{|c|c|c|c|c|c|c|}
\hline & \multicolumn{2}{|c|}{$\begin{array}{l}\text { Sports Sciences } \\
\quad(n=112)\end{array}$} & \multicolumn{2}{|c|}{$\begin{array}{l}\text { Other than Sports Sciences } \\
\qquad(\mathbf{n}=\mathbf{1 0 7})\end{array}$} & \multirow[t]{2}{*}{$\mathbf{U}$} & \multirow[t]{2}{*}{$\mathbf{p}$} \\
\hline & $\bar{x}$ & SD & $\bar{x}$ & SD & & \\
\hline \multicolumn{7}{|l|}{ FPCS } \\
\hline Total Score & 85.96 & 30.20 & 70.00 & 25.36 & 4128.500 & $<0.001 *$ \\
\hline Identity & 16.87 & 6.95 & 14.20 & 5.94 & 4703.500 & 0006* \\
\hline Emotional Commitment & 17.89 & 5.62 & 14.84 & 5.63 & 4167.000 & $<0.001 *$ \\
\hline Resource Cost & 10.54 & 4.62 & 8.20 & 4.02 & 4071.500 & $<0.001 *$ \\
\hline Psychological Cost & 11.93 & 5.21 & 9.50 & 4.33 & 4371.500 & 0001* \\
\hline Social Obligation & 9.31 & 3.98 & 7.40 & 3.16 & 4287.000 & $<0.001 *$ \\
\hline Regional Commitment & 19.41 & 7.99 & 15.86 & 7.01 & 4389.500 & 0001* \\
\hline \multicolumn{7}{|l|}{ SSTR } \\
\hline Total Score & 97.97 & 24.86 & 87.10 & 21.77 & 4141.500 & $<0.001 *$ \\
\hline Team Performance & 14.66 & 4.94 & 13.07 & 4.36 & 4788.000 & 0010* \\
\hline Team Tradition & 18.54 & 4.77 & 18.39 & 3.49 & 4848.000 & 0008* \\
\hline Social Responsibility & 20.17 & 5.68 & 17.35 & 5.91 & 4336.000 & $<0.001 *$ \\
\hline Spectator-Orientation & 14.88 & 4.37 & 13.10 & 4.07 & 4234.000 & $<0.001 *$ \\
\hline Management Quality & 15.47 & 5.54 & 12.77 & 4.75 & 4133.000 & $<0.001 *$ \\
\hline Financial Performance & 14.25 & 4.32 & 12.43 & 4.52 & 4618.500 & 0003* \\
\hline
\end{tabular}

Note. $*: \mathrm{p}<0.05$.

The results given in Table 4 show that there is a significant difference between the groups in the total score and all subscales of both scales according to the university department. All scores of the sports sciences students were significantly higher compared to the scores of students studying in a department other than sports sciences $(\mathrm{p}<0.05)$. 


\section{Macrothink}

Table 5. Mann-Whitney U Test Results of FPCS and SSTR Scores by "Membership to a Fan Union"

\begin{tabular}{|c|c|c|c|c|c|c|}
\hline & \multicolumn{2}{|c|}{ Member $(n=68)$} & \multicolumn{2}{|c|}{ Not a Member $(n=151)$} & \multirow{2}{*}{$\mathbf{U}$} & \multirow{2}{*}{$\mathbf{p}$} \\
\hline & $\overline{\boldsymbol{x}}$ & SS & $\bar{x}$ & SS & & \\
\hline \multicolumn{7}{|l|}{ FPCS } \\
\hline Total Score & 91.57 & 31.34 & 72.12 & 25.79 & 3299.000 & $<0.001 *$ \\
\hline Identity & 18.87 & 7.32 & 14.07 & 5.68 & 3191.000 & $<0.001 *$ \\
\hline Emotional Commitment & 18.87 & 5.08 & 15.29 & 5.80 & 3330.500 & $<0.001 *$ \\
\hline Resource Cost & 11.60 & 4.74 & 8.40 & 4.00 & 3071.500 & $<0.001 *$ \\
\hline Psychological Cost & 12.71 & 5.15 & 9.86 & 4.59 & 3484.500 & $<0.001 *$ \\
\hline Social Obligation & 10.03 & 4.19 & 7.64 & 3.24 & 3381.500 & $<0.001 *$ \\
\hline Regional Commitment & 19.50 & 7.99 & 16.85 & 7.48 & 4124.000 & $0.020 *$ \\
\hline \multicolumn{7}{|l|}{ SSTR } \\
\hline Total Score & 101.46 & 24.65 & 88.70 & 22.65 & 3324.500 & $<0.001 *$ \\
\hline Team Performance & 15.44 & 4.51 & 13.18 & 4.67 & 3785.000 & $0.002 *$ \\
\hline Team Tradition & 18.65 & 4.33 & 18.39 & 4.13 & 4426.500 & 0.076 \\
\hline Social Responsibility & 21.13 & 5.91 & 17.74 & 5.68 & 3331.000 & $<0.001 *$ \\
\hline Spectator-Orientation & 15.43 & 4.43 & 13.37 & 4.11 & 3524.500 & $<0.001 *$ \\
\hline Management Quality & 16.53 & 5.20 & 13.08 & 5.05 & 3132.000 & $<0.001 *$ \\
\hline Financial Performance & 14.28 & 4.54 & 12.95 & 4.44 & 4218.000 & $0.034 *$ \\
\hline
\end{tabular}

Note. $*: \mathrm{p}<0.05$.

There was no statistically significant difference between the scores obtained in the team tradition subscale of Spectator-Based Sports Team Reputation Scale according to the status of membership to a fan union according to the results given in Table $5(\mathrm{p}<0.05)$.

Apart from this subscale, there is a significant difference between the groups in the total score and all subscales of both scales according to the status of membership to a fan union. All scores of the students who had a membership to a fan union were significantly higher $(\mathrm{p}<$ $0.05)$. 


\section{IIacrothink}

Table 6. Kruskal-Wallis test results of FPCS and SSTR scores by "team supported"

\begin{tabular}{|c|c|c|c|c|c|c|c|c|c|c|c|c|c|}
\hline & \multicolumn{2}{|c|}{$\begin{array}{c}\text { Fenerbahçe }^{1} \\
(n=64)\end{array}$} & \multicolumn{2}{|c|}{$\begin{array}{l}\text { Beşiktaş }^{2} \\
(n=44)\end{array}$} & \multicolumn{2}{|c|}{$\begin{array}{c}\text { Galatasaray }^{3} \\
(\mathrm{n}=\mathbf{7 4})\end{array}$} & \multicolumn{2}{|c|}{$\begin{array}{c}\text { Trabzonspor }^{4} \\
(\mathrm{n}=\mathbf{2 6})\end{array}$} & \multicolumn{2}{|c|}{$\begin{array}{l}\text { Other }^{5} \\
(\mathrm{n}=11)\end{array}$} & \multirow[t]{2}{*}{$\mathbf{x}^{2}$} & \multirow[t]{2}{*}{$\mathbf{p}$} & \multirow[t]{2}{*}{ post-hoc } \\
\hline & $\bar{x}$ & SS & $\bar{x}$ & SS & $\overline{\boldsymbol{x}}$ & SS & $\bar{x}$ & SS & $\bar{x}$ & SS & & & \\
\hline \multicolumn{14}{|l|}{ FPCS } \\
\hline Total Score & 81.97 & 30.68 & 88.89 & 30.99 & 69.84 & 23.00 & 82.42 & 27.50 & 59.00 & 30.91 & 17.560 & $0.002 *$ & $2>3$ \\
\hline Identity & 15.94 & 7.06 & 18.52 & 7.54 & 13.88 & 4.70 & 16.31 & 6.42 & 11.09 & 6.56 & 16.451 & $0.002 *$ & $2>3-5$ \\
\hline Emotional Commitment & 17.22 & 5.52 & 18.50 & 5.80 & 14.78 & 5.38 & 17.04 & 5.46 & 12.64 & 7.46 & 17.240 & $0.002 *$ & $2>3$ \\
\hline Resource Cost & 9.78 & 4.99 & 11.18 & 4.51 & 8.00 & 3.12 & 10.35 & 5.12 & 7.18 & 4.45 & 17.942 & $0.001 *$ & $2>3-5$ \\
\hline Psychological Cost & 11.92 & 4.89 & 12.20 & 5.15 & 9.47 & 4.46 & 10.31 & 4.60 & 7.64 & 5.24 & 17.810 & $0.001 *$ & $1-2>3$ \\
\hline Social Obligation & 8.63 & 4.18 & 9.64 & 3.97 & 7.55 & 2.98 & 8.85 & 3.27 & 6.36 & 3.88 & 14.693 & $0.005^{*}$ & $2>3$ \\
\hline Regional Commitment & 18.48 & 8.22 & 18.84 & 8.00 & 16.15 & 6.97 & 19.58 & 7.76 & 14.09 & 6.50 & 8.315 & 0.081 & - \\
\hline \multicolumn{14}{|l|}{ SSTR } \\
\hline Total Score & 98.81 & 21.13 & 100.61 & 20.85 & 84.77 & 22.70 & 92.31 & 25.75 & 79.00 & 35.21 & 20.824 & $<0.001 *$ & $1-2>3$ \\
\hline Team Performance & 13.92 & 4.85 & 16.25 & 4.14 & 12.99 & 4.16 & 13.65 & 4.97 & 10.73 & 5.93 & 19.620 & $0.001 *$ & $2>3-5$ \\
\hline Team Tradition & 19.66 & 2.98 & 19.32 & 3.50 & 17.74 & 4.73 & 17.88 & 4.03 & 14.45 & 5.94 & 17.289 & $0.002 *$ & $1-2>5$ \\
\hline Social Responsibility & 19.88 & 5.69 & 21.20 & 5.37 & 17.12 & 5.33 & 18.08 & 6.07 & 15.73 & 8.87 & 17.900 & $0.001 *$ & $2>1-3$ \\
\hline Spectator-Orientation & 15.22 & 3.77 & 14.93 & 3.88 & 12.78 & 4.18 & 13.35 & 5.10 & 13.09 & 5.61 & 13.714 & $0.008 *$ & $1>3$ \\
\hline Management Quality & 15.08 & 4.76 & 16.14 & 5.02 & 11.91 & 4.92 & 15.38 & 5.43 & 13.00 & 7.21 & 23.060 & $<0.001 *$ & $1-2-4>3$ \\
\hline Financial Performance & 15.06 & 4.12 & 12.77 & 4.40 & 12.23 & 4.07 & 13.96 & 4.98 & 12.00 & 6.07 & 17.897 & $0.001 *$ & $1>2-3$ \\
\hline
\end{tabular}

Note. $\bar{x}$ : mean, SD: standard deviation $*: \mathrm{p}<0.05$.

A significant difference was found between the scale scores according to the team they supported. The table shows which groups caused the differences according to the results of the post hoc analysis.

The total score of the Fan Psychological Commitment Scale was significantly higher in Beşiktaş fans compared to Galatasaray fans $(\mathrm{p}<0.05)$.

The total score of Spectator-Based Sports Team Reputation Scale of Fenerbahçe and Beşiktaş fans was significantly higher compared to Galatasaray fans $(p<0.05)$. 


\section{Macrothink}

Table 7. Correlation analysis results for the relationship between FPCS and SSTR

\begin{tabular}{|c|c|c|c|c|c|c|c|c|c|}
\hline & \multicolumn{7}{|c|}{ Spectator-Based Sports Team Reputation Scale } \\
\hline & & & $\begin{array}{l}\text { Total } \\
\text { Score }\end{array}$ & $\begin{array}{l}\text { Team } \\
\text { Performance }\end{array}$ & $\begin{array}{l}\text { Team } \\
\text { Tradition }\end{array}$ & $\begin{array}{l}\text { Social } \\
\text { Responsibility }\end{array}$ & $\begin{array}{l}\text { Spectator- } \\
\text { Orientation }\end{array}$ & $\begin{array}{l}\text { Management } \\
\text { Quality }\end{array}$ & $\begin{array}{l}\text { Financial } \\
\text { Performance }\end{array}$ \\
\hline \multirow{14}{*}{ 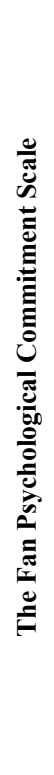 } & \multirow{2}{*}{ Total Score } & $\mathrm{r}$ & 0.645 & 0.609 & 0.488 & 0.637 & 0.521 & 0.604 & 0.387 \\
\hline & & $\mathrm{p}$ & $<0.001 *$ & $<0.001 *$ & $<0.001 *$ & $<0.001 *$ & $<0.001 *$ & $<0.001 *$ & $<0.001 *$ \\
\hline & \multirow{2}{*}{ Identity } & $\mathrm{r}$ & 0.622 & 0.569 & 0.386 & 0.629 & 0.516 & 0.572 & 0.356 \\
\hline & & $\mathrm{p}$ & $<0.001 *$ & $<0.001 *$ & $<0.001 *$ & $<0.001 *$ & $<0.001 *$ & $<0.001 *$ & $<0.001^{*}$ \\
\hline & \multirow{2}{*}{ Emotional Commitment } & $\mathrm{r}$ & 0.689 & 0.553 & 0.498 & 0.697 & 0.583 & 0.671 & 0.372 \\
\hline & & $\mathrm{p}$ & $<0.001 \%$ & $<0.001 *$ & $<0.001 *$ & $<0.001 *$ & $<0.001 *$ & $<0.001 *$ & $<0.001 *$ \\
\hline & \multirow{2}{*}{ Resource Cost } & $\mathrm{r}$ & 0.619 & 0.500 & 0.442 & 0.619 & 0.516 & 0.594 & 0.343 \\
\hline & & $\mathrm{p}$ & $<0.001 *$ & $<0.001 *$ & $<0.001 *$ & $<0.001 *$ & $<0.001 *$ & $<0.001 *$ & $<0.001 *$ \\
\hline & \multirow{2}{*}{ Psychological Cost } & $\mathrm{r}$ & 0.602 & 0.557 & 0.503 & 0.610 & 0.505 & 0.545 & 0.332 \\
\hline & & $\mathrm{p}$ & $<0.001 *$ & $<0.001 *$ & $<0.001 *$ & $<0.001^{*}$ & $<0.001^{*}$ & $<0.001 *$ & $<0.001^{*}$ \\
\hline & \multirow{2}{*}{ Social Obligation } & $\mathrm{r}$ & 0.441 & 0.396 & 0.228 & 0.447 & 0.332 & 0.419 & 0.330 \\
\hline & & $\mathrm{p}$ & $<0.001$ * & $<0.001 *$ & $<0.001 *$ & $<0.001 *$ & $<0.001 *$ & $<0.001 *$ & $<0.001^{*}$ \\
\hline & \multirow{2}{*}{ Regional Commitment } & $\mathrm{r}$ & 0.399 & 0.510 & 0.330 & 0.372 & 0.273 & 0.355 & 0.285 \\
\hline & & $\mathrm{p}$ & $<0.001 *$ & $<0.001 *$ & $<0.001 *$ & $<0.001 *$ & $<0.001 *$ & $<0.001 *$ & $<0.001 *$ \\
\hline
\end{tabular}

Note. $*: \mathrm{p}<0.05$.

Positively significant relationships were found between the entire Fan Psychological Commitment Scale and all its subscales and Spectator-Based Sports Team Reputation Scale and all its subscales $(p<0.05)$. The increase or decrease in one of the scores affects the other scores in the same direction. There is a positive and strong, statistically significant relationship between the two scales $(r=0.645 ; \mathrm{p}<0.001)$.

Table 8. Regression Analysis Results for the Relationship between FPCS and SSTR

\begin{tabular}{|l|l|l|l|l|l|l|}
\hline Independent Variable & Dependent Variable & $\mathrm{B}$ & Std. Error & $(\beta)$ & $\mathrm{t}$ & $\mathrm{p}$ \\
\hline \multirow{2}{*}{ SSTR } & Constant & 6.961 & 6.069 & - & 1.147 & 0.253 \\
\cline { 2 - 8 } & FPCS & 0.768 & 0.063 & 0.635 & 12.116 & $<\mathbf{0 . 0 0 1} *$ \\
\hline $\mathbf{R}=0.635, \mathbf{R}^{\mathbf{2}}=0.404, \mathbf{F}=146.798, \mathbf{p}<0.001$ \\
\hline
\end{tabular}

Note. $*: \mathrm{p}<0.05$.

When the results of the analysis were examined, it was seen that Spectator-Based Sports Team Reputation level predicted Fan Psychological Commitment level significantly $(\mathrm{R}=$ $\left.0.635, \mathrm{R}^{2}=0.404, \mathrm{~F}=146.798, \mathrm{p}<0.001\right)$. It was observed that $40 \%\left(R^{2}=0.404\right)$ of the total 
variance on Fan Psychological Commitment was explained by Spectator-Based Sports Team Reputation.

\section{Discussion and Conclusions}

In this study conducted to determine the relationship between the reputation of sports team perceived by university students and their psychological commitment to their teams and to examine these according to some variables;

It was found that the gender variable did not make a significant difference on SSTR whereas it made a significant difference on FPCS. Göksel et al. (2020) examined the psychological commitment of 446 university students to the team they were supporters of, and it was revealed that male supporters had higher psychological commitment scores to the team compared to female supporters. It can be said according to the current study that the results are consistent with the literature (Gençay \& Karaküçük, 2006; Giray \& Salman, 2008; Sarı et al., 2011; K1lıç, 2020; Polat et al., 2018). The high level of psychological commitment to the team in male fans compared to female fans also proves that men's interest in and tendencies towards football are higher in Turkey compared to women. There was no significant difference between the total scores of psychological commitment to the team and the total scores of their perceived sports team reputation in the university student fans according to their age groups in this study. Similarly, Can et al. (2020) did not find a significant relationship between the age variable and fan commitment. Another study found that there was no relationship between the age variable and fan identification level (Polat et al., 2018). Another study conducted on 205 football fans concluded that the level of psychological commitment to the team did not show a significant difference according to the age variable (Kartal \& İnan, 2018). Relying on these studies similar to our research results, it was concluded that commitment may not be an age-based structure. Many individuals support a team from an early age, and that does not change easily. Therefore, it can be said that the psychological commitment to the team that emerges at young ages does not differ according to the age variable. The results show that psychological commitment to the team supported by a student and perceived sports team reputation differ in terms of the department they are studying in. The department variable is divided into 2 categories as "sports sciences" and "other than sports sciences." Accordingly, both FPCS and SSTR total scores of university students studying sports sciences were found to be significantly higher than the scores of students studying in a department other than sports sciences. Sports club's recruitment of students who graduated from sports sciences departments may lead to the recruitment of committed staff according to these results. There are studies in the literature supporting the research results (Bozyiğit \& Doğan, 2018). The research results show the difference in the psychological commitment to the supported team by a student and the perceived sports team reputation according to the status of membership to a fan union and the team the students support. This is also supported by some other studies in the literature. Hacisoftaoğlu et al. (2006) in their study that the level of fan commitment in fan union members was high. Membership to a fan union is fun for individuals and it also gives social status and a sense of belonging to the team (Eker Öğüt, 2010). Göksel et al. (2020) conducted a study on university students, and it was seen that university student supporters of Fenerbahçe received 
higher scores in terms of their commitment to the team compared to supporters of other teams. Beşiktaş supporters are a fanatical group that experiences group belonging at extremes with nationalist discourses, slogans, and social projects, according to Ögüt Eker (2010). The total score of FPCS was significantly higher in Beşiktaş fans compared to Galatasaray fans in our study. SSTR total scores of Fenerbahçe and Beşiktaş fans were significantly higher compared to Galatasaray fans.

Correlation analysis is used to determine the direction and level of the relationship between the two variables. Correlation coefficient (r) varies between -1 and +1 . A positive and strong relationship was found between the reputation of the sports team perceived by university students and their psychological commitment to their teams at the level of 0.01 . In other words, as the reputation level of the sports team perceived by university students increases, the students' level of psychological commitment to their teams also increases. Or, as the level of reputation of the sports team perceived by university students decreases, the students' level of psychological commitment to their teams also decreases. There are other studies indicating that team reputation has positive effects on fan commitment (Elahi et al., 2018; Jang et al., 2015; Walsh et al., 2009; Walsh \& Beatty, 2007; Shruti, 2015; Gul, 2014). To which extent the independent variable can explain the dependent variable is determined by regression analysis. Regression analysis was applied to the SSTR and FPCS variables, and the level of the SSTR variable affecting the FPCS variable was determined. According to the regression, SSTR level significantly predicted FPCS level $\left(\mathrm{R}=0.635, \mathrm{R}^{2}=0.404, \mathrm{~F}=146.798, \mathrm{p}<\right.$ 0.001). In other words, Spectator-Based Sports Team Reputation is responsible for $40 \%$ of Fan Psychological Commitment.

The literature review shows that there are very few studies conducted within the framework of sports team reputation. Therefore, current results of our research may form the basis for the findings in future studies.

As a result, hypotheses $1,3,4$, and 5 were accepted whereas hypotheses 2 were rejected based on the results of the psychological commitment of university students to their teams. Hypotheses 3, 4, and 5 were accepted whereas hypotheses 1 and 2 were rejected based on the results regarding the reputation of the sports team. In addition, the H6 which was hypothesized as "There is a linear relationship between the reputation of the sports team perceived by the participants and their psychological commitment to their teams" was accepted. The results show that psychological commitment to the team supported by a student and perceived sports team reputation differ in terms of the department they study in, the status of membership to a fan union, and the team they support. However, it was found that the gender variable did not make a significant difference on perceived sports team reputation whereas it made a significant difference on the psychological commitment to the team. It was found that the age variable did not make any difference both on psychological commitment and perceived sports team reputation.

Sports clubs or organizations need to manage their relationships with fans in order to maintain and increase their commitment to the team as many researchers working in the field of sports marketing suggest. Providing fast and quality service, delivering announcements via 
message, the use of personal media, and qualified marketing programs can be ensured for this purpose. All sports organizations want to increase the number of sports spectators with a high degree of commitment. It may be necessary to first identify commitment factors, improve and develop performance and marketing programs in order to do this.

The relationship between team reputation and psychological commitment ican be examined in different sample groups in the future. Studies can be conducted on participants from different nationalities and the effects of cultural aspects related to fan psychological commitment and sports team reputation can be investigated.

\section{References}

Anderson, E. W., Fornell, C., \& Lehmann, D. R. (1994). Customer satisfaction, market share, and profitability: Findings from Sweden. Journal of Marketing, 58(3), 53-66. https://doi.org/ $10.1177 / 002224299405800304$

Bozgeyikli, H., Taşğın, Ö., \& Eroğlu, S. E. (2018). A study about the validity and reliability of the Turkish version of Fan Psychological Commitment Scale. OPUS-International Journal of Society Researches, 9(16), 481-497. https://doi.org/10.26466/opus.481001

Can, B., Kendirli, K., \& Polat, E. (2020). Examination of the relationship between basketball and football spectator' level of fan identification, communication skills and aggression. International Journal of Contemporary Educational Studies, 6(2), 243-264.

Caruana, A., \& Ewing, M. T. (2010). How corporate reputation, quality, and value influence online loyalty. Journal of Business Research, 63(9-10), 1103-1110. https://doi.org/10.1016/ j.jbusres.2009.04.030

Eker Öğ̈̈t, G. (2010). Irressistable charming of the football, portrait of fascinated supporter, fanaticism and Besiktas. Milli Folklor International and Quarterly Journal of Cultural Studies, 22(85), 174.

Elahi, A., Mahmoudi, B., \& Akbari Yazdi, H. (2018). The impact of team reputation and team quality on the loyalty of the fans of Iranian National Volleyball Team: A mediating role of satisfaction. Annals of Applied Sport Science, 6(4), 39-48. https://doi.org/10.29252/aass journal.6.4.39

Gençay, S., \& Karaküçük, S. (2006). A research upon behaviours sport supporter concerned with of the university students. Gazi Journal of Physical Education and Sports Sciences, 4, $11-22$.

Giray, C., \& Gültekin Salman, G. (2008). The relationship between psychological commitment and aggression of the fans of Fenerbahce Sport Clubs. Istanbul Commerce University Journal of Social Sciences, 13, 147-157.

Gladden, J. M., \& Funk, D. C. (2001). Understanding brand loyalty in professional sport: examining the link between brand associations and brand loyalty. International Journal of Sports Marketing and Sponsorship, 3(1), 54-81. https://doi.org/10.1108/IJSMS-03-012001-B006 


\section{MInstitute Macrothink $^{\text {Int }}$}

Göksel, A. G., Zorba, E., Yıldı, M., \& Caz, Ç. (2020). The examination of the psychological commitment of the students in the faculty of sport sciences to the football team that they support. OPUS-International Journal of Society Researches, 15(25), 3800-3818. https://doi.org/10.26466/opus.623549

Gotsi, M., \& Wilson, A. M. (2001). Corporate reputation: Seeking a definition. Corporate Communications: An International Journal, 6(1), 24-30. https://doi.org/10.1108/1356328011 0381189

Gul, R. (2014). The relationship between reputation, customer satisfaction, trust, and loyalty. Journal of Public Administration and Governance, 4(3), 368-87. https://doi.org/10.5296/ jpag.v4i3.6678

Hacısoftaoğlu, İ., Akcan, F., Üstüntaş, S., \& Bulgu, N. (2006). Bir Alt Kültür Olarak Futbol Taraftarlığg: Ankaragücü Pegasus Taraftar Kulübü Örneği. Proceedingof the $9^{\text {th }}$ International Sport Sciences Congress (p. 868). Mugla, Turkey.

Hart, A. E., \& Rosenberger, P. J. (2004). The effect of corporate image in the formation of customer loyalty: An Australian replication. Australian Marketing Journal, 12(3), 88-96. https://doi.org/10.1016/S1441-3582(04)70109-3

Hill, B., \& Green, B. C. (2000). Repeat attendance as a function of involvement, loyalty, and the sportscape across three football contexts. Sport Management Review, 3, 145-162. https://doi.org/10.1016/S1441-3523(00)70083-0

Hong, S. Y., \& Yang, S. U. (2009). Effects of reputation, relational satisfaction, and customer-company identification on positive word-of-mouth intentions. Journal of Public Relations Research, 21(4), 381-403. https://doi.org/10.1080/10627260902966433

Jang, W., Ko, Y. J., \& Chan-Olmsted, S. M. (2015). Spectator-based sports team reputation: scale development and validation. International Journal of Sports Marketing and Sponsorship, 16(3), 52-72. https://doi.org/10.1108/IJSMS-16-03-2015-B005

Kartal, M., \& İnan, H. (2018). An investigation of the psychological dependence levels of soccer fans (Sample of Adiyaman Province). Journal of Institute of Economic Development and Social Researches, 4(14), 730-735. https://doi.org/10.31623/iksad.111

Kılıç, A. (2020). Relationship between identification levels of football fans and their curiosity levels: Samsunspor fans example (Unpublished master thesis, Ordu University, Graduate School of Health Sciences, Ordu).

Mahony, D. F., Madrigal, R., \& Howard, D. A. (2000). Using the Psychological Commitment to Team (PCT) Scale to segment sport consumers based on loyalty. Sport Marketing Quarterly, 9(1), 15-25.

Matsuoka, H. (2001). Multidimensionality of fans' Psychological Commitment tos port teams: Development of scale (Unpublished doctoral thesis, The Ohio State University, USA).

Nguyen, N., \& Leblanc, G. (2001). Corporate image and corporate reputation in customers' 
retention decisions in services. Journal of Retailing and Consumer Services, 8(4), 227-236. https://doi.org/10.1016/S0969-6989(00)00029-1

Polat, E., Yoka, K., \& Üzüm, H. (2018). Taraftar özdeşleşme düzeyi ve yaşam tatmini arasındaki ilişkinin incelenmesi. 3th International Eurasian Conference on Sport, Education, and Society, November 15-18, 2018, Mardin, Turkey.

Ponzi, L. J., Fombrun, C. J., \& Gardberg, N. A. (2011). RepTrakTM Pulse: Conceptualizing and validating a short-form measure of corporate reputation. Corporate Reputation Review, 14(1), 15-35. https://doi.org/10.1057/crr.2011.5

Ross, S. D. (2006). A conceptual framework for understanding spectatorbased brand equity. Journal of Sport Management, 20, 22-38. https://doi.org/10.1123/jsm.20.1.22

Sarı, İ., Eskiler, E., \& Soyer, F. (2011). Does psychological commitment to team enhance self-esteem? An easy way to raise self-esteem. International Journal of Humanities and Social Science, 1(19), 187-196.

Shawn, S., \& Philip, J. R. (2012). The influence of involvement, following sport and fan identification on fan loyalty: An Australian perspective. International Journal of Sports Marketing and Sponsorship, 13(3), 57-71. https://doi.org/10.1108/IJSMS-13-03-2012-B006

Shruti, M. (2015). Relationship of customer based corporate reputation and customer perceived value-A case of automobile sector. International Journal of Computing and Corporate Research, 5(1), 2249-54.

Suchao-in, K., Gulthawatvichai, S., \& Chatpunyakul, C. (2021). Mediating role of sports team reputation: The relationships between team brand association, satisfaction, and loyalty in professional Thai football league. Kasetsart Journal of Social Sciences, 42, 221-226. https://doi.org/10.34044/j.kjss.2021.42.1.35

Tüfekçi, Ö. K., \& Bağış, Y. E. (2016). Effect of quality perception for psychological commitment, identification levels licensed products on purchase intention of the supporter. Journal of Current Researches on Social Sciences, 6(1), 103-116.

Walsh, G., \& Beatty, S. E. (20047). Customer-based corporate reputation of a service firm: Scale development and validation. Journal of the Academy of Marketing Science, 35(1), 127-43. https://doi.org/10.1007/s11747-007-0015-7

Walsh, G., Mitchell, V. W., Jackson, P. R., \& Beatty, S. E. (2009). Examining the antecedents and consequences of corporate reputation: A customer perspective. British Journal of Management, 20(2), 187-203. https://doi.org/10.1111/j.1467-8551.2007.001557.x

Wang, R. T., \& Zhang, J. J., \& Tsuji, Y. (2011). Examining fan motives and loyalty for the Chinese Professional Baseball League of Taiwan. Sport Management Review, 14(4), 347-60. https://doi.org/10.1016/j.smr.2010.12.001

Wonseok, E. J., Yong, J. K., \& Sylvia, M. C. O. (2015). Spectator-based sports team reputation: Scale development and validation. International Journal of Sports Marketing and 
Sponsorship, 16(3), 52-72. https://doi.org/10.1108/IJSMS-16-03-2015-B005

Yavuz Eroğlu, S., \& Eroğlu, E. (2020). Adaption of the spectator-based sports team reputation into Turkish: A validity and reliability study. International Journal of Eurasian Education and Culture, 5(10), 1704-1721. https://doi.org/10.35826/ijoecc.249

Yousaf, A., Bashir, M., \& Mishra, A. (2020). Revisiting Spectator-Based Sports Team Reputation: Strategic Implications for team managers. Corporate Reputation Review, 23, 1-12. https://doi.org/10.1057/s41299-019-00068-y

\section{Copyright Disclaimer}

Copyright for this article is retained by the author(s), with first publication rights granted to the journal.

This is an open-access article distributed under the terms and conditions of the Creative Commons Attribution license (http://creativecommons.org/licenses/by/3.0/). 